\title{
O IMAGINÁRIO DA DÉCADA DE 1920 NO CINEMA BRASILEIRO
}

\section{Resumo}

Neste artigo a proposta principal é enfocar o cinema brasileiro dos primeiros tempos na perspectiva de uma leitura semiótica e no domínio da Ciência da Informação. Os filmes em questão não se inscrevem como documentários, mas sim como filmes de ficção e fornecem informações sobre o imaginário de uma época, narrado pelos seus autores. Faz-se um estudo desses filmes e considera-se que o estilo de uma época é o aspecto essencial de um sentimento coletivo. Este sentimento poderá estar substanciado nas expressões artísticas, no caso o cinema brasileiro da década de 1920.

Palavras-chave: Análise semiótica; Filmes brasileiros (1920); Fontes de informação e filmes.

\section{THE IMAGINARY OF THE 1920`S IN BRAZILIAN CINEMA}

\section{Abstract}

In this article the main proposal is focus the Brazilian movies of the initial stages under the view of semiotic analyses and domain of information science. The films in question are not documentaries, but fictional films, which supply information on the imaginary narrated by their authors. These films are studied form a poetical perspective, considering that the style of a period is the essential aspect of a collective feeling, which may be substantiated by artistic expressions; in this case the Brazilian movies of the 1920's.

Keywords: Semiotic analyses; Brazilian movies (1920); Films and information sources.
Rosa Inês de Novais Cordeiro Doutora em Comunicação e Cultura (ECO-UFRJ).

Professora do Departamento de Ciência da Informação e do PPGCl

da UFF

igneznovais@uol.com.br

Lídia Brandão Toutain

Doutora em Filosofia pela Universidad de León. Diretora do Instituto de

Ciência da Informação da Universidade Federal da Bahia (ICl/UFBA).

Ibrandao@ufba.br 


\section{INTRODUÇÃO}

A intenção deste artigo é abordar o cinema brasileiro dos primordios, em particular sua terceira época, que abrange o período de 1923 a 1933, e propor a sua leitura em uma perspectiva semiótica e como fonte de informação para os estudos em Ciência da Informação. Privilegiamos como objeto de estudo três filmes mudos, em preto e branco: Aitaré da Praia (1926) de Gentil Roiz; A Filha do Advogado (1926) de J. Soares; e, de Humberto Mauro, ${ }^{1}$ Thesouro Perdido (1927).

No âmbito internacional, a primeira década do cinema abrange o período de 18941899 a 1906-1908, e a segunda, o de 1906-1908 a 1913-1915. Essas décadas são denominadas "cinema dos primórdios", "cinema das origens", "o primeiro cinema" ou "cinema dos inícios" e caracterizam-se pela geração de filmes documentários (cinema de "atrações", de tipo espetacular, registros de acontecimentos) e filmes ficções.

No Brasil, esses períodos vão corresponder às chamadas primeira época do cinema brasileiro, que vai de 1896 a 1912, e segunda época, 1912 a 1922. Outro período importante foi à terceira época do nosso cinema, de 1923 a 1933. Neste artigo, propomo-nos fazer uma visita ao imaginário ficcional "narrado" nos filmes e pontuá-los por um estudo semiótico, sem qualquer intenção de realizar uma análise fílmica no sentido stricto.

Nosso estudo visa a examinar um objeto artístico concreto (o filme), que é passível de análise, "isolando-o de manifestações correlatas, sem configurar uma categorização estética, mas podendo contribuir, eventualmente, para a compreensão" (JACOBBI, 2002, p. 7) das obras artísticas da área do conhecimento envolvida e do "estilo de cultura". Percebemos "que a estética em questão não é, de nenhuma forma, aquela que se pode situar no domínio das belas artes: ela as engloba, mas também se estende ao conjunto da vida social" (MAFFESOLI, 1995, p. 53). Diante disso, acreditamos que pesquisas dessa natureza possam contribuir para as especialidades da Ciência da Informação, como, por

\footnotetext{
${ }^{1}$ Os filmes de Humberto Mauro são densamente analisados por Gomes (1974).

${ }^{2}$ Gunning escolhe o termo atração para designar um tipo de experiência vivida pelos visitantes de feiras, parques de diversões, museus de monstruosidades. A ideia básica é a de que o cinema de atrações se dirige diretamente à audiência, oferecendo surpresas chocantes, muitas vezes com a intermediação de um showmanexibidor-comentador (COSTA, 1995, p. 7).
}

PontodeAcesso, Salvador, v. 4, n. 1, p. 3-18, abril. 2010.

www.pontodeacesso.ici.ufba.br 
exemplo, os estudos sócio-culturais que enfocam os filmes como fontes de informação ou a especialidade da organização da informação quando trata da análise e indexação de filmes.

Considerando que a obra fílmica é resultante de expressão artística produzida em determinada época, procuraremos evidenciar que os filmes fornecem informações sobre o imaginário de seus autores (diretores, produtores) e, em consequência, refletem as ideias fragmentadas de uma sociedade e são registros e fontes de informação de importância privilegiada para a Ciência da Informação. Portanto, a análise de filmes tem sido uma prática de trabalhar no contemporâneo épocas passadas e atuais. "Não a imagem que não implique em uma construção do mundo e do seu significado" (MAGARIÑOS DE MORENTIN, 2005). Porém, conforme lembra este autor e na dimensão da contradição, "existem imagens que guardam maior semelhança com as formas dos objetos do mundo", ou seja, existem imagens mais semelhantes as formas que vê o olho humano.

Neste momento, recuperamos a proposta semiótica de Magariños de Morentin (2005) sobre a interação entre a produção, a interpretação e a transformação do significado dos fenómenos sociais e denominada "interacción constructiva". Isto é, no mundo se produz a transformação de entidades perceptíveis para determinado indivíduo ou grupo social através da relação de três elementos: pensamento, semioses, mundo. As entidades perceptíveis que não eram observáveis porque faltavam nomeações, poderão em um novo estado de semiose se interrelacionar, mediante a vigência desses novos enunciados e nomeações que emergirão dessa interação. Portanto, abrem-se possibilidades interpretativas admissíveis na configuração dinâmica do pensamento nessa nova instância interativa.

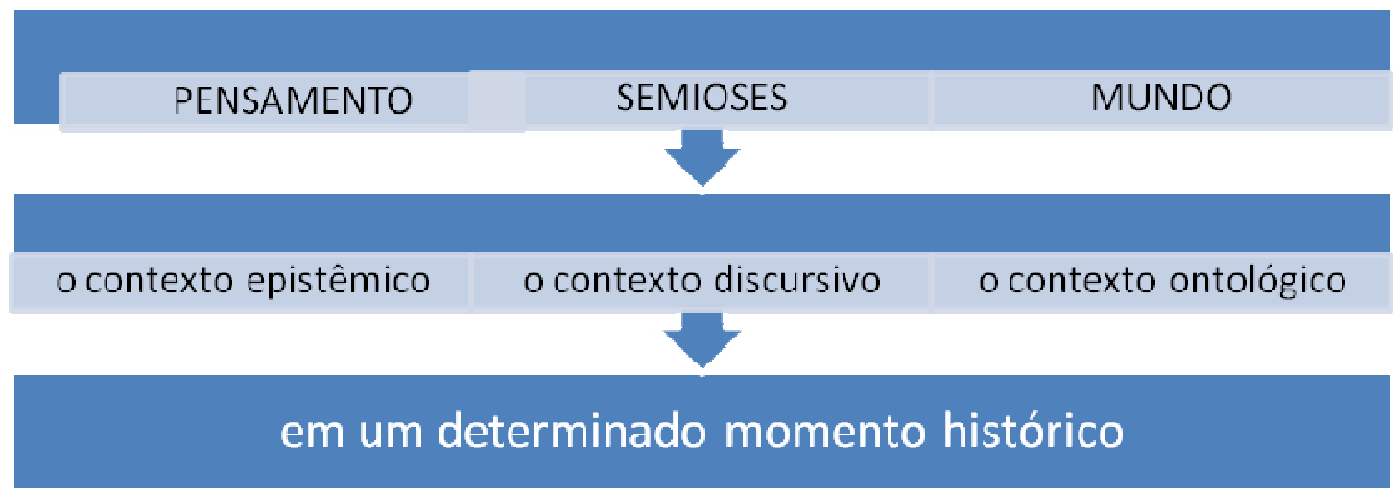

Fonte: Magariños de Morentin (2005). 
Pois bem, é nessa interação que ocorre o que Bettetini (1996) denomina como uma proposta semiótica da conversação audiovisual, na qual a obra audiovisual apresenta os seguintes sujeitos : a) o sujeito transmissor empírico (diretor, produtor); b) o sujeito enunciador/ da enunciação (significantes do texto, ou seja, fonte do discurso produzida pelo próprio discurso), c) o sujeito do enunciado (o conteúdo das mensagens, por exemplo, enunciadas pelos personagens de um filme), d) o sujeito enunciatário (receptor do texto, o destinatário do discurso construído pelo próprio discurso. Isto é, a mensagem é criada tendo em vista um receptor), e) o sujeito receptor empírico (o espectador), f) sujeito enunciador modelo (receptor do enunciador). A partir disso, Brito (1998), explica o ponto de vista de Bettetini sobre o sujeito da enunciação fílmica:

corresponde, na verdade, a um aparato conceitual ausente construído tecnicamente (ângulos, movimentos de câmera, montagem, etc.). Segundo Bettetini, este aparato 'vê', as coisas antes do espectador e pelo espectador, induzindo projetivamente um comportamento adequado de 'leitura'. Constrói-se, desse modo, o próprio "olhar" do espectador para o texto no interior desse próprio texto, colocando-o simbolicamente no lugar deste ausente: o 'ponto de vista' da câmera corresponde, em última instância, a própria noção do sujeito enunciatário de um filme. Esse aparato corresponde também a ausência de 'quem' é colocado pelo espectador no lugar da câmera, ou seja o sujeito enunciador. Nos textos cinematográficos, vê-se de modo ainda mais nítido este sincretismo entre enunciador e enunciatário (= aparato técnico) que, conceitualmente, corresponde a própria idéia de sujeito da enunciação qualquer que seja a natureza do texto em questão.

O uso da palavra enunciação deve ser evitado no cinema, no sentido de discurso

fílmico, a preferência deve ser pelo uso da “locução 'instância de enunciação' para designar a sede virtual da produção do texto" ${ }^{3}$, pois:

[...] esta instância de enunciação decide entre exibir ou esconder a sua presença no filme. Manifesta-se opor toda uma série de processos: - os olhares de câmara, comentários e mensagens ao espectador, feitos pelo realizador [...] ou pelas personagens; - as imagens objectivas irreais, impossíveis de diegetizar, ângulos de filmagem estranhos, enquadramentos invulgares e os efeitos demasiado marcados: tudo o que nos deixa perceber o estilo; - a reflexividade, as citações de outros filmes, que indicam uma relação particular do texto com outros textos (JOURNOT ,2005, p. 54).

\footnotetext{
${ }^{3}$ Cf. Journot, Marie-Thérèse ( 2005, p.53, 54).
} 
Cordeiro (2009, p. 8) observa que "um filme é supostamente produzido para um espectador ideal, isto é, a produção de sentido é pensada a partir de um espectador idealizado pelo autor do filme, e é este suposto espectador que terá a compreensão total dos enunciados da linguagem fílmica". Journot (2005, p. 53) afirma que o "filme é um discurso fabricado por e para alguém, ao contrário do mundo, que não se enuncia".

Aqui dois comentários devem ser acentuados: a) estamos trabalhando com filmes mudos e não podemos nomeá-los como audiovisuais, pois o áudio não integrava os filmes dessa época. Entretanto, é viável trabalharmos com o modelo de Bettetini, considerando que temos nos filmes analisados imagens e movimentos, situação que diferenciou o cinema dos primórdios das demais expressões artísticas da época (pintura, fotografia entre outras); b) a nossa discussão ficará restrita ao sujeito transmissor empírico (diretor, produtor), e o sincretismo entre o sujeito enunciador, o sujeito enunciatário e o sujeito receptor, tendo em vista o modelo de conversação audiovisual de Bettetini, mas que denominaremos como instância de enunciação.

\section{O CONTEXTO SITUACIONAL E A GERAÇÃO DOS FILMES}

O sentido de um filme pode ser analisado nas circunstâncias possíveis de suas ocorrências, quando, então, poderá ser realizado o resgate parcial do contexto situacional da sua produção, a fim de construirmos proposições de análise e demonstração. Portanto, a seguir procuraremos apontar um amplo painel desse contexto.

Inicialmente no cinema não havia qualquer preocupação com a estrutura narrativa dos filmes, com a história ou mesmo considerações de ordem estética, mas, por outro lado, o relevante era o registro de acontecimentos, atualidades e paisagens. Embora as cenas registradas fossem desprovidas de uma narrativa explícita, elas provocavam grande sensação, devido à novidade do movimento ${ }^{4}$ das imagens e à produção de sentido imediato que essas provocavam nas pessoas, graças a sua aproximação com o cotidiano. Assim,

\footnotetext{
${ }^{4}$ Tentativas anteriores existiram com o intuito de provocar a ilusão do movimento. 
[...] os primeiros filmes só podiam ser entendidos pelo espectador através de referências externas, provenientes do contexto sociocultural da época (piadas [anedotas] correntes, notícias recentes, cantigas populares, cartoons, peças de teatro famosas, romances) ou da explicação que era fornecida pelo comentador. (COSTA, 1995, p.88).

A princípio, os filmes eram vistos individualmente por cada espectador, através do quinetoscópio (1894), de Thomas Edison, mas logo “outros homens tomavam-lhe a dianteira, exibindo publicamente pequenas fitas, mesmo antes dos Irmãos Lumière" ${ }^{5}$ (ROSENFELD, 2002, p. 61). O cinematógrafo Lumière passou a ser um "espetáculo" de consumo coletivo e simultâneo, realizado inicialmente por "pseudo-diretores", que contavam com atores-anônimos. A "filmagem" ficava ao sabor da luz natural e de ambientes ao ar livre, e os locais de exibição eram determinados pela exibidor ambulante que "procurava os lugares mais receptivos, instalando o seu projetor em feiras, parques de diversões, quermesses ou apresentando a sua mercadoria em festas de beneficência e onde quer que houvesse afluência popular" (ROSENFELD, 2002, p. 67). Já no início do século XX os teatros de vaudeville exibem ${ }^{6}$, em suas salas, filmes em geral de qualidade duvidosa e de pequena duração (em média o máximo de 15 minutos). Além disso, exibiam-se fitas em outros ambientes, de modo a ampliar o universo de espectadores e o tamanho dos "cineteatros fixos".

Nos anos 1920, o cinema, entre outras expressões artísticas, adquire, uma importância singular, pois o contexto social e econômico era solo fértil para a promoção da novidade, ainda mais tendo a classe proletária da época mostrado avidez por esse entretenimento de baixo custo econômico, pouco intelectualizado e de consumo imediato.

No cenário brasileiro, a década de 1920 foi um período marcado pelo descontentamento social, principalmente quanto aos aspectos econômicos e políticos do velho regime. Novos grupos surgiram e "a burguesia urbana começou a se organizar e a propor medidas para reformar o regime, garantir a sua participação e promover o seu

\footnotetext{
${ }^{5}$ Apesar das divergências dos autores quanto à datação para marco do nascimento do cinema, muitos consideram 28 de dezembro de 1895 como a data oficial, em razão da exibição pública ocorrida no Grand Café de Paris, no Boulevars des Capucines.

${ }^{6}$ Fitas de qualidade duvidosa e de pequena duração (máximo de 15 minutos).
} 
desenvolvimento" (SANTOS et al, 2002, p. 292). O sonho da democracia rondava o desejo de alguns setores.

Um processo de renovação artística era reclamado por artistas e intelectuais que "promoviam movimentos de renovação cultural", marcados pela efervescência de movimentos artísticos que aspiravam mudanças substanciais. Como fatos marcantes nesse período, temos às manifestações de contestação cultural, e em especial a Semana de Arte Moderna ${ }^{7}$. Faz parte desse contexto a fundação, em 1922, do Partido Trabalhista Brasileiro por intelectuais e operários que "apoiavam as revoluções socialistas do mundo" (SANTOS et al. , 2002, p. 292). Ainda, para Lorenzo e Costa (1997, p. 8) nessa época, “[...] o país viveu uma espécie de 'aceleração da história', com a emergência de novos atores políticos (classe operária, camadas médias urbanas, militares) e novas ideias, que se expressavam não apenas no plano da política, como também nas transformações da sensibilidade e do gosto".

A sétima arte não estava presente na efervescência da Semana de Arte Moderna, e de acordo com Xavier esse fato já era esperado, se ponderarmos que "[...] não havia uma prática cinematográfica 'modernista`e brasileira, conforme o caráter das manifestações da Semana exigia" ( XAVIER, 1978, p. 145). Este autor constata, ainda, a mesma ausência do tema cinema nas discussões em artigos das revistas de cultura da época. Nas revistas, as ausências ganham um significado diferente, pois elas são em geral abrangentes em sua atitude crítica e, apesar da existência de um cinema a tematizar, não apresentam em sua matéria diversificada nem sequer uma crítica regular. Quando ele não está totalmente ausente, aparece num artigo isolado que nada acrescenta ao ideário das revistas francesas ou em algumas notas a propósito de filmes brasileiros.

Diversos motivos podem ser considerados como ambiente de fundo do distanciamento do cinema das outras manifestações artísticas. Uma das razões especuladas na literatura para tal situação é de âmbito ideológico/moralista, pois o cinema, ao contrário de outras expressões artísticas, exibia e representava o universo cultural popular. Além

\footnotetext{
${ }^{7}$ No Teatro Municipal de São Paulo, de 11 a 18 de fevereiro de 1922, aconteceu uma semana artística promovida por intelectuais, escritores, pintores, e na qual eram vistas as novas tendências das diversas manifestações artísticas.
}

PontodeAcesso, Salvador, v. 4, n. 1, p. 3-18, abril. 2010.

www.pontodeacesso.ici.ufba.br 
disso, a sétima arte impunha o novo, ${ }^{8}$ o desconhecido, fosse pelo uso da técnica, pela possibilidade de viabilizar na realidade concreta o anseio da sociedade pelo imediatismo do entretenimento (divertimento das massas), por promover o devir imediato de uma sociedade que era, já nesta época, protagonizada por astros e estrelas, ${ }^{9}$ ou ainda por retratar o contemporâneo da época. Entretanto, esse novo contexto do cinema não era contemplado no conceito de modernidade da Semana ${ }^{10,11}$.

Sem entrarmos na discussão sobre imagens plenas e vazias, e levando em conta o contexto socioeconômico e o quadro no qual se constituía o cinema brasileiro da época, a fruição da imagem em movimento funcionava como um "vetor de comunhão" da sociedade popular, e a possível mensagem ficava em um segundo plano. O importante era "compartilhar emoções", e talvez essa desconfiança em relação ao cinema vista pela intelectualidade da época, estivesse relacionada com o que Maffesoli (1995, p. 94) denomina "aversão pela aparência". Desse modo, vejamos:

[...] é interessante observar que todas as épocas, nas quais ocorre cesura de importância, vêem ressurgir, senão o mesmo problema, pelo menos uma questão equivalente. $O$ medo da imagem, tal como uma serpente marinha, ressurge regularmente, quando uma maneira de estar-junto dá lugar, progressivamente, a uma outra, com a inquietude que não deixa de suscitar. Há um momento de pânico diante da coisa nova, e por isso misteriosa, que ainda não se domina bem, e que progressivamente irá encontrar seu equilíbrio: a imagem em sua manutenção, em seu declínio ou em seu nascimento. [...] Ela nada vale por si mesma, mas, em movimento de reversibilidade, extrai sua força do todo social no qual se integra, do todo social que constitui, que ela evoca e epifaniza, com maior ou menor beleza (MAFFESOLI, 1995, p. 96 e 99).

\footnotetext{
${ }^{8}$ COSTA (1995, p. 52) esclarece que “Uma das idéias equivocadas pelas histórias clássicas do cinema é a de que os primeiros filmes foram uma enorme novidade, diante da qual o público mostrou desconfiança ou grande espanto. Talvez na tenha sido exatamente assim. Como mostram os trabalhos de historiadores mais recentes, o cinema surgiu como uma prática autônoma mas, ao contrário, veio como mais um dos aperfeiçoamentos das técnicas óticas que eram utilizadas nos espetáculos de magia, nas apresentações de palestras auxiliadas por aparelhos de lanterna mágica, ou nos chamados 'espetáculos totais' — onde se procurava simular experiências da realidade de forma artificial, com uma proposta semelhante à chamada 'realidade virtual' de hoje".

${ }^{9}$ Nessa época os atores protagonistas não eram anônimos, a ideia do lançamento de estrelas estava difundida no universo do cinema.

${ }^{10}$ Xavier (1978, p.146) entende que o modernismo que inspirava as novas gerações de intelectuais procurava "Diante da loucura e quase 'barbárie' do mundo moderno," uma solução que "[...]seria a prática de um "modernismo" continuador da tradição, fiel às legítimas vocações espirituais a terra brasileira".

${ }^{11}$ Assim como o rádio, o cinema era visto com desconfiança por certa parcela da elite: "A mentalidade do grande público está afinada para o cinema, a revista, o circo e o futebol. A elite numa minoria esmagadora retrae-se desconsolada". Citação publicada na revista Festa n. 8, jun. 1928 (apud XAVIER, 1978, p. 146).
}

PontodeAcesso, Salvador, v. 4, n. 1, p. 3-18, abril. 2010. 


\section{OS FILMES ANALISADOS: INDÍCIOS SOBRE O IMAGINÁRIO DE UMA ÉPOCA}

Os filmes estudados neste artigo são narrativos ${ }^{12}$ e utilizam, de diversas formas, intertítulos para a explicação da trama, e têm uma preocupação de natureza estética. Podemos exemplificar o cuidado com a ilustração dos intertítulos pelas frases que acompanham as imagens representativas do enredo do filme A Filha do Advogado (1926). No filme Áitaré da Praia (1926), houve a preocupação em inserir nos intertítulos letras das músicas encenadas ou em poetizá-los, por exemplo, com o texto de Victor Hugo "vós que soffreis porque amais, amai mais aindda. Morrer de amor, é viver d'elle", ou numa indicação de passagem de tempo "seis horas, hora do crespusculo e da saudade"13.

Nos primeiros filmes, o efeito diegético não se consumava ("regime de mostração"). Já nos filmes da época analisada, obtém-se tal efeito, pois há intenção do autor em construir um enredo.

Contudo, em poucas e determinadas sequências de alguns filmes, ocorre ainda o encobrimento da diegese, e isto acontece "todas as vezes em que aparecem sinais de que se trata de um discurso construído" (COSTA, 1995, p. 7).

Nos filmes em questão, a narrativa é desenhada numa intenção da linearidade absoluta da trama, apesar da existência de "embaralhamento de cenas-fragmentos". Ocorrem também elipses e indicações de simultaneidade da narrativa (em outro espaçotempo ocorre determinada ação). Segundo Gomes (1974, p.139), nos filmes de Humberto Mauro, "[...] a partir do Thesouro Perdido (1927)", há um "rigor de construção global até então desconhecido no cinema brasileiro" (GOMES, 1974, p. 139). O previsto é antecipado pela singeleza dos acontecimentos, dos precários recursos e conhecimentos técnicos de filmagem e montagem (edição) que se tinha na época. Contudo, como o entendimento da narrativa se faz pela interpretação do movimento das imagens e dos intertítulos, em certas situações a originalidade espacial e temporal inesperada do autor surpreende o espectador. São admiráveis, na obra de Humberto Mauro, a dinâmica da trama e a evolução técnica de

\footnotetext{
${ }^{12}$ Primeiro período: 1894-1895 a 1906-1908 filmes não narrativos; segundo período: 1906-1908 a 1913-1915 aumenta a narrativa nos filmes (COSTA, 1995, p. 8).

${ }^{13}$ Mantida a grafia original do texto dos intertítulos.
} 
uma obra para outra. Entretanto, neste artigo não temos como objetivo o enfoque do ponto de vista da técnica de filmagem, mas sim enveredar por uma leitura das obras, procurando especular sobre o imaginário nelas narrado por seus autores. Neste momento, acreditamos ser pertinente o esclarecimento de Maffesoli (1995, p.43), acentuando o "[...] fato que o estilo da época pode ser, ao mesmo tempo, 'evidente', para aqueles que o vivenciam, e totalmente opaco, para os que tentam analisá-lo".

Nos filmes investigados, as tramas se desenvolvem com uma certa constância, a partir de um núcleo familiar dilacerado dos protagonistas. Seja pela ausência da figura feminina da mãe por motivo de morte, ou simplesmente pela omissão da figura materna, seja pela ausência de ambos os pais, a família não aparece como representação da Santíssima Trindade. Nas narrativas, a figura masculina do pai, de caráter forte, que ampara os filhos, sob a égide da justiça e da moralidade, e do homem bem sucedido na vida é idealizada. Quando há ausência do pai, surge um parente protetor ou um amigo virtuoso e salvador, de caráter não duvidoso. A amizade pelo pai e amigo é incontestável.

O ébrio, o inebriar-se pelo amor - amor proibido, "amor bandido", amor flertado, amor lírico - e/ou pelo dinheiro, e/ou por uma posição social são os argumentos dos filmes. O sentimento e a emoção desnudam os corpos, cuidadosamente cobertos pelo rigor moral da época, e encadeiam os dramas. Fazendo uma analogia com Roberto DaMatta, no que se refere "à casa e à rua" no Brasil, vemos nos filmes de Humberto Mauro a construção de um comportamento feminino sob a ótica da "mulher da casa" antagônica a "mulher da rua". A figura idealizada é protagonizada pela mulher que desempenhada predominantemente o papel da "mulher na casa", porém poucas outras "Marias" ilustram o papel da "mulher na rua" (por exemplo, surgiram em revistas masculinas, ou não estão presentes), mas não existem interlocuções diretas entre esses papéis desempenhados. No filme $A$ Filha do Advogado (1926) a personagem D. Lucinda, a não esposa, promove uma interlocução "sutil" sobre os valores familiares e sociais da época, reforçados pela objetividade da informação fornecida pelos intertítulos. Vejamos este pequeno texto: 
- Como quase todos os homens, o Dr. Paulo trasia consigo um grande segredo.

- Possuo uma filha natural, rebento das minhas extravagancias de rapaz, e que por conveniências, conservo-a longe daqui.

- Dona Lucinda Correia, amante do Dr. Paulo, quando solteiro, e mãe de Heloisa (mantida a grafia do texto dos intertítulos).

Em resposta à pergunta: "O que fazia a mulher brasileira do começo do século? Schapochnik (1998, p. 519) assinala a vinculação dessa figura feminina à "mulher de casa" burguesa: "Na vida real, ela respondia pela administração da casa, pela cozinha, pelas roupas dos filhos, pela limpeza" [...] e os "prazeres da vida" podiam ser pontuados pelos os "chás, o baile, a praia, o piquenique e o jogo de tênis [...]".

Dos filmes consultados, acreditamos que, em A Filha do Advogado (1926), há sequências que insinuam a modalidade de "filmes do tipo buraco-de-fechadura, onde personagens voyeurs espiam a vida alheia por instrumentos ópticos ou buracos de fechadura" (COSTA, 1995, p.100). A curiosidade é acirrada entre o bom moço e o vilão, olhando pela fechadura, bem como entre o mordomo e o jardineiro. Este último assiste a todo clímax da trama do filme pelo buraco da fechadura, quando a mocinha trava luta com o playboy vilão, em defesa de sua honra. Outra sequência, chega à comicidade, quando o mordomo que estava olhando ocultamente pelo buraco da fechadura cai desastradamente da posição de observador e vai ao chão, quando abrem a porta.

Partindo da preleção de Maffesoli (1995, p.94) de que "[...] a imagem constata um élan vital, uma estética (aisthesis) emocional em todos os seus afetos, sejam eles refinados, de mau gosto, despojados, kitsch, explosivos ou conformistas", o imaginário, nos filmes aqui analisados, se esboça em pretos e brancos que sugerem as dualidades: bem/mal, belo/ grotesco, feio/sublime, trágico/cômico. Entre uma unidade dramática construída na linguagem silenciosa do objetivismo da trama e do subjetivismo no registro do tempo e do espaço, algumas vezes estes são solapados pela ausência de uma estrutura narrativa ou pelo singelo encadeamento dos fatos narrativos, além do possível desaparecimento de personagens. 
No âmbito do grotesco, temos como exemplo uma "técnica" empregada no cinema da época: a "autodefinição da personagem pela maneira de tratar os animais" (GOMES, 1974, p.177). Essa técnica era usada explicitamente, e com frequência, nos filmes de Humberto Mauro, como por exemplo, em Thesouro Perdido (1927), quando o vilão Manoel Faca (interpretado pelo próprio Humberto Mauro) açoita violentamente um gato - ato um tanto ou quanto desnecessário, pois o caráter vilão da personagem já estava explicitado para o espectador. Talvez o mineiro Humberto Mauro, que era pela crítica elogiado por ter em seus filmes a preocupação "com os aspectos característicos brasileiros e com a nacionalidade", ponto fundamental da época , não resistiu a uma pitada de estilização estrangeira no caldo cultural brasileiro. Segundo Gomes, sua influência mais próxima talvez esteja na película lançada no Brasil em outubro de 1924, como David, o Caçula [Tolable David, de Henry King], e muito bem apreciada pela jovem crítica [...]. Humberto Mauro não só esse filme assistiu, mas estudou-o. Nesse filme, o vilão principal mata um cachorro com uma pedra, logo em uma de suas primeiras aparições (GOMES, 1974, p. 144 e 177). Por outro lado, o carinho pelos animais poderia autodefinir as personagens por seu caráter do bem. É curioso que o cineasta dê tanta a importância ao drama, no filme citado, em particular a um cachorro-personagem, pois nos chama atenção no filme da imagem obtida do animal ${ }^{14}$ em primeiro plano e em close de estrelato, embora o personagem-animal vá ser assassinado na trama. Curiosamente, no filme $A$ Filha do Advogado (1926), temos uma cena, um tanto mais modesta fotograficamente, em que o cachorro é o único personagem, e sua vinculação com a trama é ilustrativa.

Ainda faz parte desse contexto dual e ambíguo o espaço da cena formado pela ideia de límpido e turvo, em particular nos filmes de Humberto Mauro. No ambiente límpido, o conjunto dos elementos que compõem o cenário sugere ao espectador a percepção da limpeza do ambiente; é criada uma atmosfera de dramaticidade, em alusão a um sentimento harmonioso, cujas sequências congregam personagens e ideias da moral "do bem", ao passo que acontece o contrário nas cenas em que o ambiente é preparado para dar a impressão de sujeira: nelas, a ação é impulsionada pelo clima do sentimento desarmonioso e por

\footnotetext{
14 "Sentado numa pedra, Velludo é visto de baixo, de corpo inteiro, a silhueta contra o céu (GOMES, 1974, p. 149).
} 
personagens do lado vilão. O mesmo ocorrendo com a caracterização da personagem, por exemplo, em Aitaré da Praia: a barba do vilão Zeno é emblemática para o cenário límpido, praiano, singelo e belo da natureza nordestina com seus pescadores e jangadeiros.

Outro influência da técnica estrangeira em Humberto Mauro e outros cineastas da época é a "fotogenia da fumaça", como por exemplo as cenas de incêndio que ele construía em seus filmes. Em outros filmes vê-se também a apologia à poética da fumaça, mostrando chaminés de navios ou trens, jorrando fumaça.

O costume de fumar da época e a sua vinculação a uma suposta condição social eram também trazidos às telas de cinema por meio de cachimbos, charutos e cigarros. Criavam-se portanto estereótipos que eram incutidos no imaginário social desse hábito, oriundo da Europa. Assim, multiplicam-se nos filmes personagens, tais como: o dono de boteco, com um permanente charuto; o bandido, com o cigarro meio caído; o senhor "bem nascido", em posições elegantes, com cachimbo ou cigarros bem postados à boca. Curiosamente, Sevcenko (1998, p. 529) cita o escritor-jornalista João do Rio, que sugere: "para saber a que sociedade pertence um homem, basta vê-lo fumar. Jacques fumando era de primeira classe [...]. Por isso mesmo seu traje preferido era o smoking jacket, com o qual frequentava o smoking room dos clubes da cidade, dividindo seu tempo entre o poker e o flirt". Entretanto, no ambiente rural, era hábito fumar ou mascar fumo de rolo (Aitaré da Praia 1926). Sevcenko (1998, p.529) também esclarece que o hábito de fumar charuto era associado à virilidade: representava "o prestígio das posições conquistadas, o prêmio do sucesso, a consagração de uma reputação, trazendo como corolário a admiração feminina, a promessa de maiores prazeres e novas conquistas". Por outro lado, eram raros os casos de mulheres fumantes, embora em 1920 já houvesse fotos que retratavam esse hábito. Daí que "a identificação do cigarro com a mulher jovem e ousada, além de dotar o novo hábito de uma forte carga erótica, integrava a gesticulação que acompanhava o ato de fumar à linguagem corporal da sedução (SEVCENKO, 1998, p. 529).

Contudo, temos nessas películas a figura feminina dirigindo no mundo alucinado dos veículos que estão presentes nos filmes. Em alguns dos filmes, tem-se a impressão que o cineasta está deslumbrado nem tanto com o veículo (carros de passeio, trens), mas com a possibilidade do movimento ser levado às telas. 
Poderíamos resgatar muitas outras vinculações temáticas referentes ao imaginário cultural e social de um contexto brasileiro de época, representado e narrado em diversas formas nos filmes pela idealização de seus autores para os espectadores, mas, também, fruída por esses espectadores/receptores. Portanto, essas instâncias de enunciação são simulacros semióticos e integram o paradoxo da representação fílmica, ou seja, o "paradoxo de uma presença ausente" ${ }^{15}$. Machado (2007, p.73) resgata: "a imagem é sempre considerada incompleta, pois, se não o fosse, não haveria lugar para o observador" é o "imaginário do espectador que preenche no ato da leitura" o espaço vazio que exige uma 'leitura fantasmática por parte do espectador [...]".

As categorias (estilo de época, dramas sociais, relacionamento social e familiar, acontecimentos e situações sociais, gênero, gênero, tramas e assuntos recorrentes, etc.) resultantes da análise do filme e do contexto situacional da época poderão ser potencializadas como importantes elementos para estudos de Ciência da Informação, no que tange a tentativa de ampliar o uso dos filmes como fonte de informação ficcional, mas indicadora de indícios, por exemplo, culturais, sociais, estéticos de uma época.

\section{CONSIDERAÇÕES FINAIS}

Acreditamos que temáticas imperativas foram exploradas de forma tangencial, em virtude da complexidade do universo que envolve a questão. Tentamos rever os filmes em uma livre associação de ideias entre o que é mostrado e o que é visto e, por conseguinte, buscamos pensar sobre essa "estética dos prazeres compartilhados", a partir do estudo de alguns filmes brasileiros da década de 1920. Tentamos um diálogo inicial entre a Semiótica e a Ciência da Informação considerando o processo de significação de um mesmo objeto de estudo.

\footnotetext{
${ }^{15}$ Cf. Aumont (2004, p. 153)
}

PontodeAcesso, Salvador, v. 4, n. 1, p. 3-18, abril. 2010.

www.pontodeacesso.ici.ufba.br 


\section{REFERÊNCIAS}

AUMONT, Jacques. O olho interminável: cinema e pintura. São Paulo: Cosac \& Naify, 2004.

BETTETINI, G. La conversacion audiovisual. Madrid: Cátedra, 1996.

BRITO, Yvana Carla Fechine de. Cinema, televisão e vídeo: uma proposta de abordagem semiótica da recepção. In: CONGRESSO DA ASSOCIAÇÃO LATINOAMERICANA DE PESQUISADORES EM COMUNICAÇÃO, 4., 1998, Recife. Anais... Recife: ALAIC, 1998.

Disponível em: <www.eca.usp.br/alaic/Congreso1999/5gt/Yvana\%20Carla\%20.rtf>. Acesso em: 10 fev. 2010.

CORDEIRO, Rosa Inês de Novais. A recepção do espectador de filmes: parâmetros para a análise indexadora? In: SEMINÁRIO ABERTO DO GRUPO DE PESQUISA, IMAGEM, MEMÓRIA E INFORMAÇÃO, 2009, Brasília. Anais... Brasília: UNB; CID, 2009 (No prelo).

COSTA, F. C. O primeiro cinema. São Paulo: Scritta, 1995.

GOMES, P. Humberto Mauro, Cataguases, Cinearte. São Paulo: Perspectiva, 1974.

JOURNOT, Marie-Thérèse. Vocabulário de cinema. Lisboa: Edições 70, 2005.

LORENZO, H. de; COSTA, W. (Org.). A década de 1920 e as origens do Brasil moderno. São Paulo: Ed. UNESP, 1997.

MACHADO, Arlindo. 0 sujeito na tela: modos de enunciação no cinema e no ciberespaço. São Paulo: Paulus, 2007.

MAFFESOLI, M. A contemplação do mundo. Porto Alegre: Artes e Ofícios, 1995.

No fundo das aparências. 2.ed. Petrópolis: Vozes, 1996.

MAGARIÑOS DE MORENTIN, Juan. La semiótica de los Bordes. 2005. Disponível em: <www.centro-de-semiotica.com.ar>. Acesso em: 12 fev. 2010.

Semiótica de las imágenes visuales. 2002. Disponível em: <www.centro-desemiotica.com.ar>. Acesso em: 12 fev. 2010.

NAHL, Diane; BILA, Dania (Ed.). Information and emotion: the emergent affective paradigm in information behaviour research and theory. New Delhi, Ess Ess Publications: Medford, Information Today, 2008.

RAULINO, B. Ruggero Jaccobbi. São Paulo: Perspectiva, Fapesp, 2002.

PontodeAcesso, Salvador, v. 4, n. 1, p. 3-18, abril. 2010.

www.pontodeacesso.ici.ufba.br 
ROSENFFELD, A. Cinema: arte \& indústria. São Paulo: Perspectiva, 2002.

SANTOS, A. et al. História do Brasil: de "Terra Ignota" ao Brasil atual. Rio de Janeiro: Logon, 2002.

SCHAPOCHNIK, Nelson. Cartões-postais, álbuns de família e ícones da intimidade. In: NOVAIS, Fernando A. (Coord.); SEVCENKO, Nicolau. História da vida privada no Brasil. São Paulo: Companhia das Letras, 2001. v. 3.

SEVCENKO, Nicolau. A capital irradiante: técnica, ritmos e ritos do Rio. In: NOVAIS, Fernando A. (Coord.); SEVCENKO, Nicolau. História da vida privada no Brasil. São Paulo: Companhia das Letras, 2001. v. 3.

SHATFORD, S. Analyzing the subject of a Picture: a theoretical approach. Cataloging \& Classification Quarterly, v. 6, n. 3, p.39-62, 1986.

SHATFORD LAYNE, Sara. Subject access to art images. In: BACA, Murtha (Ed.). Introduction to art image access: issues, tools, standards, strategies. Los Angeles: J. Paul Getty Trust, 2001. . Some issues in the indexing of images. JASIS, v. 45, n. 8, p.583-588, 1994.

XAVIER, I. Sétima arte: um culto moderno. São Paulo: Perspectiva, 1978. 